Sea slugs - divers' favorites, taxonomists' problems

Jensen, Kathe

Published in:

Aquatic Science \& Management

Publication date:

2013

Document version

Publisher's PDF, also known as Version of record

Document license:

Unspecified

Citation for published version (APA):

Jensen, K. (2013). Sea slugs - divers' favorites, taxonomists' problems. Aquatic Science \& Management, 1(2), 100-110. http://ejournal.unsrat.ac.id/index.php/jasm/article/view/7271 


\title{
Sea slugs - divers' favorites, taxonomists' problems
}

\author{
Siput laut - disukai para penyelam, masalah bagi para taksonom
}

\author{
Kathe R. Jensen \\ Zoological Museum (Natural History Museum of Denmark), Universitetsparken 15, DK-2100 Copenhagen $\emptyset$, Denmark \\ E-mail: krjensen@snm.ku.dk
}

\begin{abstract}
Sea slugs, or opisthobranch molluscs, are small, colorful, slow-moving, non-aggressive marine animals. This makes them highly photogenic and therefore favorites among divers. The highest diversity is found in tropical waters of the Indo-West Pacific region. Many illustrated guidebooks have been published, but a large proportion of species remain unidentified and possibly new to science. Lack of funding as well as expertise is characteristic for taxonomic research. Most taxonomists work in western countries whereas most biodiversity occurs in developing countries. Cladistic analysis and molecular studies have caused fundamental changes in opisthobranch classification as well as "instability" of scientific names. Collaboration between local and foreign scientists, amateurs and professionals, divers and academics can help discovering new species, but the success may be hampered by lack of funding as well as rigid regulations on collecting and exporting specimens for taxonomic research. Solutions to overcome these obstacles are presented.
\end{abstract}

Keywords: mollusca; opisthobranchia; biodiversity; citizen science; taxonomic impediment

\begin{abstract}
Abstrak: Siput laut, atau moluska golongan opistobrancia, adalah hewan laut berukuran kecil, berwarna, bergerak lambat, dan tidak bersifat agresif. Alasan inilah yang membuat hewan ini sangat fotogenik dan menjadi favorit bagi para penyelam. Keanekaragaman tertinggi hewan ini ditemukan di perairan tropis Indo-Pasifik bagian Barat. Banyak buku petunjuk tentang hewan ini telah diterbitkan, tetapi sebagian besar spesimen belum teridentifikasi dan bisa menjadi hal baru bagi ilmu pengetahuan. Kekurangan dana dan keahlian merupakan cirikhas dari penelitian taksonomi. Umumnya para taksonom bekerja di negara-negara Barat sedangkan keanekaragaman tertinggi hewan ini berada di negara-negara berkembang. Analisis cladistik dan kajian molekuler menyebabkan perubahan mendasar dalam klasifikasi opistobrancia, demikian juga sering berubahnya nama ilmiah hewan ini. Kerjasama antara ilmuan lokal dan asing, amatir dan profesional, penyelam dan akademisi dapat membantu dalam menemukan jenis-jenis baru, tetapi keberhasilannya dapat dihambat oleh kurangnya biaya dan peraturan yang kaku dalam mengumpul dan mengirim spesimen untuk penelitian taksonomi. Solusi dalam menyelesaikan masalah tersebut disampaikan dalam tulisan ini.
\end{abstract}

Kata-kata kunci: moluska; opistobrancia; biodiversitas; halangan taksonomi

\section{INTRODUCTION}

The small, often brightly colored sea slugs living in shallow waters of most tropical seas have been eyecatchers for divers and underwater photographers over the years. The most colorful species are found in coral reef habitats, which are also the preferred diving localities, but sea slugs occur in other habitats as well. Sea slugs are often called nudibranchs, but this is only part of the group scientifically known as opisthobranch molluscs (Wägele and Klussmann-Kolb, 2005). Besides the nudibranchs (Nudibranchia) (Wägele and Willan, 2000), sea slugs comprise the bubble-shells or headshield slugs (Cephalaspidea) (Mikkelsen, 1996; Malaquias et al., 2009), sea hares (Anaspidea) (Klussmann-Kolb, 2004), side-gilled slugs (Notaspidea) (Willan, 1987), sap-sucking slugs
(Sacoglossa) (Jensen, 1996) and the holoplanktonic sea butterflies (Thecosomata) and sea angels (Gymnosomata) (Klussmann-Kolb and Dinapoli, 2006). The total number of species is unknown because new species are still being described, and poorly known species turn out to be synonyms of other species. Recent estimates are given as 50006000 species worldwide (Wägele and KlussmannKolb, 2005; Schrödl et al., 2011).

Because of their often spectacular coloration and also because they are slow-moving, small and non-aggressive, they are highly photogenic and therefore favorites among underwater photographers. This is reflected in the number of popular picture books published from different countries and in different languages (e.g. Gosliner, 1987; Wells and Bryce, 1993; Debelius, 1996; Ono, 
1999; Schrödl, 2003; Behrens and Hermosillo, 2005; Camacho-Garcia et al., 2005; Valdés et al., 2006; Gosliner et al., 2008; Yonow, 2008; Chavanich et al., 2010). Few of these books are exhaustive for the region covered, though some have pictures of more than 500 species. Furthermore, although several of the books have been written by professional taxonomists, many species have only been identified to genus or family level, and many of these are assumed to be unnamed and un-described. The same is seen in the various internet sites for sharing pictures of sea slugs.

The highest species diversity occurs in the tropical Indo-West Pacific, and particular diversity hotspots have been identified in the Philippines, Papua New Guinea and Guam (Gosliner, 2000; Carlson and Hoff, 2003; Jensen, 2007). It has been estimated that $15-40 \%$ of the species in the IndoPacific region are still unnamed and un-described (Gosliner and Draheim, 1996). This explains part of the problem with identifying sea slugs from pictures. More important, however, is the high variability of color pattern and body form. Hence preserved specimens for anatomical and/or molecular studies are needed. Even then taxonomists do not always agree on the delimitation of a given species, its synonyms or its generic or family affiliations. Taxonomy is a dynamic discipline. Adding new information may result in name changes, and in recent years the opisthobranch molluscs have undergone fundamental changes in phylogenetic relationships with associated changes in names and classification (Schrödl et al., 2011).

The increasing popular interest in sea slugs is in contrast to the decreasing financial support for taxonomic research and the lack of taxonomic expertise for most marine invertebrates (Godfrey, 2002; Wheeler et al., 2004; Boero, 2010; Wägele et al., 2011). Furthermore, most taxonomists, including the few specializing in sea slugs, are located in Europe, North America and Australia, i.e. developed countries in temperate regions, whereas most biodiversity is found in the tropical Indo-West Pacific region, i.e. primarily developing countries (Gaston and May, 1992; Bouchet, 2006). Amateur taxonomists have always played an important role in discovering and describing new species (Pearson et al., 2011). In recent years scientists have developed projects including so-called "citizen science" and/or parataxonomy (Basset et al., 2000; Cohn, 2008). The present paper will present the opportunities and challenges of collaborations between professional and amateur sea slug enthusiasts and between local students and scientists in Southeast Asia and foreign expert taxonomists. Based on experience some set-ups for a fruitful collaboration between local divers, professional taxonomists and national biodiversity managers will be presented.

\section{Linnean shortfall}

The fact that a high proportion of species remain un-discovered and un-described has been termed the Linnean shortfall. Many new species of opisthobranchs are described every year, most of them based on preserved specimens accumulated by taxonomists over many years. Gosliner and Fahey (2011) described 20 new species of the arminid genus Dermatobranchus, and the included type material had been collected between 1980 and 2008 . This is not an exceptional case; in a monograph of the family Phyllidiidae 21 new species in four genera were described from type material collected between 1967 and 1992, in fact one paratype was a museum specimen from 1870 (Brunckhorst, 1993), and in a series of 10 papers reviewing Indo-Pacific Chromodorididae a total of 68 new species were described from material collected between 1970 and 1993, and again one paratype was a museum specimen from 1925 (Rudman, 1982, 1983, 1985, 1986a,b,c, 1987, 1988, 1990, 1995). This means that most taxonomists have a back-log of species that have been discovered, but not yet named and described. During most field collecting trips only one or a few specimens of each species are found, and unless many persons can be engaged in the effort, it may take several years to obtain enough material for describing a new species. Collaborating with local divers, scientists and students may greatly increase the likelihood of finding more specimens. International workshops where taxonomists from developed countries collaborate with scientists and students from developing countries have proved very successful in this respect, e.g. the workshops organized in Hong Kong by Brian Morton during the 1980s and 1990s (results summarized in Morton, 2003).

\section{Stability of names}

Scientific names are supposed to be unique descriptors of species, and when new species are described the taxonomist should consult existing descriptions of related species and ideally compare with existing type specimens to avoid creating "junior synonyms". The problems in this connection concern (1) accessibility of old descriptions, which may be in rare publications and in languages not understood by most taxonomists, e.g. Danish, 
Dutch, Russian or Japanese; (2) inadequate old descriptions with no or poor illustrations; (3) unavailable, lost or poor quality of type material (Godfrey, 2002; Bouchet and Strong, 2010). Organizations such as the Biodiversity Heritage Library (http://www.biodiversitylibrary.org/) are attempting to make old taxonomic publications available on the internet. Books and journal volumes are scanned and hence the quality of the electronic versions is variable, and language may still be a problem. Other projects build databases of taxon names and/or museum specimens, especially type specimens, e.g. World Register of Marine Species (Appeltans et al., 2012) and Global Biodiversity Information Facility (Edwards et al., 2000).

Inadequate species descriptions are not only something of the past. Present-day taxonomists will generally avoid describing new species if only one specimen is available, but sometimes such descriptions do occur, e.g. 5 of the 20 new species of Dermatobranchus were described from one specimen (Gosliner and Fahey, 2011). Other taxonomists, mostly those in favor of the PhyloCode, will include partial descriptions of species without formally assigning a binomial (Linnean) name. Thus Dayrat (2010) in a 400 page monograph of the family Discodorididae describes seven species (A-G), two of them assigned to different genera and the remaining five to a "metaphyletic genus level group", a concept elaborated in a prior paper (Dayrat and Gosliner, 2005). This concept is difficult to comprehend for an experienced taxonomist, and probably leaves other users of taxonomy flabbergasted.

Name changes happen when species are synonymized or split, often in connection with revisions and/or when phylogenetic analysis shows that a genus is not monophyletic. Unfortunately different specialists sometimes reach different conclusions resulting in unstable names rather than the opposite. The nudibranch family Chromodorididae, probably the most species-rich family of sea slugs (>300 valid species), is a good or bad - example. The first revision of the genera of this family was carried out by Rudman (1984, 1987). Next Gosliner and co-workers described additional species and revised several genera (Gosliner, 1996; Gosliner and Behrens, 1998, 2000; Johnson and Gosliner, 1998, 2001; Gosliner and Johnson, 1999; Valdés and Gosliner, 1999; Valdés et al., 1999; Johnson and Valdés, 2001; Gosliner et al., 2004; Alejandrino and Valdés, 2006). And most recently the accepted generic division was again split up and some old genus names reinstated
(Turner and Wilson, 2008; Johnson, 2010; Johnson and Gosliner, 2012). For each revision and/or phylogenetic study names have been changed, species synonymized and new species names have been introduced. Name changes make it difficult for database managers to follow the "fate" of specific taxa.

Conservation managers need stable species lists for setting priorities of protected areas (Giangrande, 2003; Mace, 2004; Khuroo et al., 2007). Also pharmacologists, physiologists and biochemists need to be certain about species identification. Faulty identifications may be worse than incomplete lists (Bortolus, 2008), and name changes resulting from phylogenetic analyses may have widely different effects on conservation actions (Morrison et al., 2009; Dayrat, 2011), though species are not actually "lost" when moved from one genus to another. Species richness may decrease if species are synonymized, but probably the combined populations then turn out to be more common and less threatened. For chemical and molecular studies it is necessary that voucher specimens are deposited in recognized museums and that publications contain information on how species were identified (Schander and Willassen, 2005; Pleijel et al., 2008; Wägele et al., 2011). For sea slugs voucher specimens should be accompanied by color pictures because colors disappear and body shape is altered by preservation (Jensen, 1999).

\section{Specimen availability}

Most divers and underwater photographers, being conscious about the environment and biodiversity conservation, "collect" only pictures of sea slugs. When taxonomists are not able to identify species from pictures and suspect that it may be an un-described species, they would like to obtain preserved specimens. This is where serious obstacles to the fruitful collaboration between local divers and foreign taxonomists may be encountered. Sea slugs are often habitat specific and thus apparently rare, i.e. only one or two specimens are observed at one time and place. In some cases it may be possible to obtain specimens by providing instructions for proper fixation and shipment to the local divers who can then collect the specimens when they see them again and ship them to the scientists. However, problems may arise if (1) the species has been observed only in a protected area where collection is prohibited, (2) there are national regulations prohibiting export of "biodiversity", (3) shipping regulations may prohibit certain kinds or quantities of chemicals used for preserving 
specimens (Renner et al., 2012). As most sea slugs are small, shipping in itself is rarely a problem. Most of the liquid fixative can be drained prior to shipping and plenty of absorbent packing material supplied to keep the specimen moist.

It is of utmost importance that collectors, whether foreign or local, professional taxonomists or amateurs, obtain the necessary permits for collecting and exporting specimens for research. Collaboration with local research institutions and universities may facilitate this process. Specimens obtained without the appropriate permits may not be accepted by museums for deposition of type material, and papers may be refused for publication if material has been obtained illegally. Many sea slugs are too small to see in the field, and it may be necessary to collect their substrate, such as hydroids, bryozoans or algae for sorting under a microscope (Jensen, 1999; Mikkelsen and Cracraft, 2001). It may be difficult to state exactly what and how much will need to be collected to obtain enough specimens of a species that has only been photographed once or a few times, but if local scientists can explain this problem to conservation officers, it should be possible to overcome this problem. Applying for a permit in connection with a collaborative general marine biodiversity workshop may be easier than trying to apply for a permit to collect a few specific organisms, which then may not be found for the duration of the permit.

Funding for taxonomic research is scarce, and most taxonomists cannot pay large fees for permits as can medical companies doing bioprospecting work. When applying for a collecting permit for taxonomic research it should be stressed that no commercial interests, such as bioprospecting, are involved, that the species are not endangered or protected by international conventions, that type material will be deposited in the country of origin (or as required by national regulations), and that published descriptions will be made available to authorities and scientists in the country of origin. For a successful collaboration, applications for collecting and export permits might also have provisions for training of local students and scientists. Further recommendations can be found in a publication from the secretariat of the Convention on Biological Diversity (CBD, 2007). Unfortunately many developing countries have bad experiences with foreign scientists collaborating with the local scientists only during the field work and then taking all the profits and patents, and it may be very difficult and costly to obtain a collecting permit (Bouchet, 2006). The fact that there may be a long time-lag between collecting specimens and publication may also leave the local collaborators frustrated (Evenhuis, 2007), but as explained above, a 10-year lag is not uncommon. Publication of separate, but peer-reviewed workshop proceedings two to three years after the workshop has been successful in the past (see review by Morton, 2003). Recent focus on Impact Factors and the like may have made this solution obsolete. On the other hand it is also necessary that the local students, divers, boat-operators, etc. do not use the information they obtain concerning rarity and value of new species to create a private business collecting and selling specimens to aquarium traders or pharmaceutical companies. Participating in basic biodiversity research carries a responsibility to utilize the information for the conservation of that biodiversity, at least to prevent the loss of biodiversity.

\section{Taxonomic problems}

Classification in the Opisthobranchia was originally based on the presence or absence of a shell and only two orders were recognized: Tectibranchia with a shell and Nudibranchia without a shell. However, it was soon realized that some "tectibranchs" were more closely related to some "nudibranchs" than to other "tectibranchs"; some sea hares had an internal shell, and the same was seen in some side-gilled slugs. In the sapsucking Sacoglossa some species had an external shell, and in 1959 a living bivalved sacoglossan was discovered (Kawaguti and Baba, 1959). Thus the shell has been reduced and/or lost in several groups of opisthobranchs (Mikkelsen, 1998; Jensen, 1999; Wägele and Klussmann-Kolb, 2005), and parallel evolution is also seen in other organ systems, such as the concentration and de-torsion of the nervous system, or the development of cerata containing branches of the digestive gland (Gosliner and Ghiselin, 1984; Huber, 1993; Jensen, 1996). Nevertheless classification remained fairly stable, with the exception of a few groups, e.g. Pyramidellidae, that have repeatedly been included and excluded (Schmekel, 1985; Graham, 1988; Jensen, 2000).

In recent years the traditional classification of the Gastropoda has been seriously challenged by increased use of cladistic analysis based on morphological characters and on molecular data, and many new names for higher taxa have been introduced (Thollesson, 1999; WollscheidLengeling et al., 2001). Presently the Opisthobranchia is included in the subclass Heterobranchia, which also comprises the Pulmonata (most of the terrestrial and freshwater snails and slugs) and some 
smaller snail families (Haszprunar, 1988; Grande et al., 2004; Wägele et al., 2008; Jörger et al., 2010). Furthermore the opisthobranchs are presently not considered a monophyletic group, and "Opisthobranchia" should therefore be in quotation marks (Schrödl et al., 2011). Molecular studies indicate relationship between the Sacoglossa and the Siphonariidae, but whether both groups should be included in a Panpulmonata group, or the Siphonariidae should be relocated to "opisthobranchs", or both are basal within the Euthyneura is unclear (Dinapoli and KlussmannKolb, 2010; Dayrat et al., 2011; Dinapoli et al., 2011), and comparative anatomical studies show only superficial similarities (Jensen, 2011). The mostly interstitial Acochlidiacea have also been moved from their traditional inclusion in "Opisthobranchia" (Jörger et al., 2010), and the recently described Aitengidae (Swennen and Buatip, 2009) has been included in the Acochlidiacea (Neusser et al., 2011).

This reorganization of opisthobranch classification has caused a lot of confusion among divers, and also among conservation biologists who like their species lists to be complete, i.e., no name changes and no unidentified species. Many professional taxonomists have been so deeply involved in the testing of new phylogenetic hypotheses that describing new species has been given low priority. Fortunately some taxonomists, including amateurs and retirees, continue to discover and describe species, and habitats other than coral reefs have yielded some interesting results (Swennen, 2001, 2007, 2011; Swennen and Buatip, 2009; Brenzinger et al., 2011; Neusser et al., 2011).

\section{The Indonesian connection}

The first sea slug described from Indonesia is probably a sea hare collected by Rumphius in Ambon in the second half of the 17th century, and later described as Dolabella rumphii Blainville, 1819 (Engel, 1942), which is currently known as $D$. auricularia (Lightfoot, 1786). Later van Hasselt described several species of opisthobranchs from Java (van Hasselt, 1824; Bergh, 1887), and later still the Siboga Expedition collected opisthobranchs, which were described by Bergh (1905). More recently some of the nudibranchs collected during the Rumphius Biohistorical Expedition in 1990 have been described (Yonow, 2001, 2011), and a checklist of molluscs from Bunaken National Park has been published in collaboration between German and Indonesian scientists (Burghardt et al., 2006). The latter illustrates the problems outlined above very well. The list contains 49 identified opisthobranch species, 9 tentatively identified (cf.), and 31 only identified to genus or family, and the authors estimated that $26 \%$ of the 89 species were undescribed. Obviously the Indonesian sea slug fauna comprise a high proportion of un-described species, but with appropriate collaborations the number of described species should become at least as high as that of the Philippines (563 species), Papua New Guinea (646 species) and Guam (485 species) (Gosliner, 2000; Carlson and Hoff, 2003).

Acknowledgements. A preliminary version of the present paper was presented at the International Seminar on Conservation of Marine Biodiversity held at Sam Ratulangi University (UNSRAT), Manado, on 27 January 2012, as part of the Marine Biodiversity workshop held at the LIPI field station in Bitung. I would like to thank UNSRAT for partially funding my participation in the seminar, and the workshop organizers, in particular Prof. Bert Hoeksema for inviting me to participate in the workshop.

\section{REFERENCES}

ALEJANDRINO, A. and VALDÉS, A. (2006) Phylogeny and biogeography of the Atlantic and eastern Pacific HypselodorisStimpson, 1855 (Nudibranchia, Chromodorididae) with the description of a new species from the Caribbean Sea. Journalof Molluscan Studies, 72, pp. 189-198.

APPELTANS, W. et al. (eds.) (2012) World Register of Marine Species [WWW]. Available from: http://www.marine species.org/ [Accessed 25/07/2012].

BASSET, Y., NOVOTNY, V., MILLER, S.E. and PYLE, R. (2000) Quantifying biodiversity: Experience with parataxonomists and digital photography in Papua New Guinea and Guyana. BioScience 50: 899-908.

BEHRENS, D.W. and HERMOSILLO, A. (2005) Eastern Pacific Nudibranchs. A Guide to the Opisthobranchs from Alaska to Central America.Monterey:Sea Challengers.

BERGH, R. (1887) Die van Hasselt'schen Nudibranchien. Notes from the Leyden Museum, 9, pp. 303-323, plate 6.

BERGH, R. (1905) Die Opisthobranchiata der Siboga Expedition. Leiden: Brill. 
BOERO, F. (2010) The study of species in the era of biodiversity: A tale of stupidity. Diversity, 2, pp. 115-126.

BORTOLUS, A. (2008) Error cascades in the biological sciences: The unwanted consequences of using bad taxonomy in ecology. Ambio, 37, pp. 114-118.

BOUCHE, P. (2006) The magnitude of marine biodiversity. Chapter 2. In: DUARTE, C.M. (ed.) The exploration of marine biodiversity. Scientific and technological challenges. Spain: Fundación BBVA, pp. 31-64.

BOUCHET, P. and STRONG, E. (2010) Historical name-bearing types in marine molluscs: an impediment to biodiversity studies? In: POLASZEK, A. (ed.) Systema Natura 250. London: CRC Press, pp. 63-74.

BRENZINGER, B., NEUSSER, T.P., GLAUBRECHT, M., HASZPRUNAR, G. and SCHRÖDL, M.(2011) Redescription and three-dimensional reconstruction of the limnicacochlidian gastropod Strubellia paradoxa (Strubell, 1892) (Gastropoda: Euthyneura) from Ambon, Indonesia. Journal of Natural History, 45, pp. 183-209.

BRUNCKHORST, D.J. (1993) The systematics and phylogeny of phyllidiid nudibranchs (Doridoidea). Recordsof the Australian Museum, Supplement, 16, pp. 1-107.

BURGHARDT, I., CARVALHO, R., EHEBERG, D., GERUNG, G., KALIGIS, F., MAMANGKEY, G., SCHRÖDL, M., SCHWABE, E., VONNEMANN, V. and WÄGELE, H. (2006) Molluscan diversity at Bunaken National Park, Sulawesi. Journal of the Zoological Society Wallacea, 2, pp. 2943.

CAMACHO-GARCIA, Y., GOSLINER, T.M. and VALDÉS, A. (2005) Guia de campo de lasbabosas marinas del Pacificoeste tropical. Field guide to the sea slugs of the tropical eastern Pacific. San Fransisco: California Academy of Sciences.

CARLSON, C. and HOFF, P.J. (2003) Theopisthobranchs of the Mariana Islands. Micronesica, 35-36, pp. 272-295.

CHAVANICH, S., HARRIS, L.G. and VORANOP, V. (2010) Nudibranchs of Thailand. Bangkok: Biodiversity Research and Training Program.

COHN, J.P. (2008) Citizen science: Can volunteers do real research? BioScience, 58, pp. 192197.
CONVENTION on BIOLOGICAL DIVERSITY (CBD) SECRETARIAT (2007) Guide to the Global Taxonomy Initiative. Montreal: Technical Series No. 30. CBD.

DAYRAT, B. (2010) A monographic revision of basal discodorid sea slugs (Mollusca: Gastropoda: Nudibranchia: Doridina). Proceeding of the California Academy of Sciences, 61(Suppl. 1), pp. 1-403.

DAYRAT, B. (2011) A warning for ecologists and conservation biologists using species checklists: How the European marine fauna "lost" all of its 16 Discodoris species (Mollusca: Gastropoda). Organisms Diversity \& Evolution, 11, pp. 75-82.

DAYRAT, B. and GOSLINER, T.M. (2005) Species names and metaphyly: a case study in Discodorididae (Mollusca, Gastropoda, Euthyneura, Nudibranchia, Doridina). Zoologica Scripta, 34, pp.199-224.

DAYRAT, B., CONRAD, M., BALAYAN, S., WHITE, T.R., ALBRECHT, C., GOLDING, R., GOMES, S.R., HARASEWYCH, M.G. and MARTINS, A.M.D.E.F. (2011) Phylogenetic relationships and evolution of pulmonate gastropods (Mollusca): New insights from increased taxon sampling. Molecular Phylogenetics and Evolution, 59, pp. 425-437.

DEBELIUS, H. (1996) Nudibranchs and Sea Snails. Indo-Pacific Field Guide. Frankfurt: IKAN-Underwasserarchiv.

DINAPOLI, A. and KLUSSMANN-KOLB, A. (2010) The long way to diversity-Phylogeny and evolution of the Heterobranchia (Mollusca: Gastropoda). Molecular Phylogenetics and Evolution, 55, pp. 60-76.

DINAPOLI, A., ZINSSMEISTER, C. and KLUSSMANN-KOLB， A. (2011) New insights into the phylogeny of the Pyramidellidae. Journal of Molluscan Studies, 77, pp. 1-7.

EDWARDS, J.L., LANE, M.A. and NIELSEN, E.S. (2000) Interoperability of biodiversity databases: Biodiversity on every desktop. Science 289, pp. 2312-2314.

ENGEL, H. (1942) The genus Dolabella. Zoologische Mededelingen, Leiden, 24, pp. 197-239.

EVENHUIS, N.L. (2007) Helping solve the "other" taxonomic impediment: completing the Eight Steps to Total Enlightenment and Taxonomic Nirvana. Zootaxa, 1407, pp. 3-12.

GASTON, K.J. and MAY, R.M. (1992) Taxonomy of taxonomists. Nature, 356, pp. 281-282. 
GIANGRANDE, A. (2003) Biodiversity, conservation, and the "Taxonomic impediment". Aquatic Conservation: Marine and Freshwater Ecosystem, 13, pp. 451-459.

GODFRAY, H.C.J. (2002) Challenges for taxonomy. Science, 417, pp. 17-19.

GOSLINER, T.M. (1987) Nudibranchs of southern Africa. A guide to opisthobranch molluscs of southern Africa. Sea Challengers and Jeff Hamann, Monterey and El Cajon.

GOSLINER, T.M. (1996) Phylogeny of Ceratosoma (Nudibranchia: Chromodorididae), with descriptions of two new species. Proceedings of the California Academy of Sciences, 49, pp. 115-126.

GOSLINER, T.M. (2000) Biodiversity, endemism, and evolution of opisthobranch gastropods on Indo-Pacific coral reefs. Proceedings of 9th International Coral Reef Symposium, 2, pp. 937-940.

GOSLINER, T.M. and BEHRENS,D.W. (1998) Five new species of Chromodoris (Mollusca: Nudibranchia: Chromodorididae) from the tropical Indo-Pacific Ocean. Proceedings of the California Academy of Sciences, 50, pp. 139-165.

GOSLINER, T.M. and BEHRENS,D.W. (2000) Two new species of Chromodorididae (Mollusca: Nudibranchia) from the tropical Indo-Pacific, with a redescription of Hypselodoris dollfusi (Pruvot-Fol, 1933). Proceedings of the California Academy of Sciences, 52, pp. 111-124.

GOSLINER, T.M., BEHRENS, D.W. and VALDÉS, A. (2008) Indo-Pacific Nudibranchs and Sea Slugs. A field guide to the world's most diverse fauna. San Francisco: Sea Challengers Natural History Books and California Academy of Sciences.

GOSLINER, T.M. and DRAHEIM, R. (1996) IndoPacific opisthobranch gastropod biogeography: how do we know what we don't know? American Malacological Bulletin, 12, pp. 37-43.

GOSLINER, T.M. and FAHEY, S.J. (2011) Previously undocumented diversity and abundance of cryptic species: a phylogenetic analysis of Indo-Pacific Arminidae Rafinesque, 1814 (Mollusca: Nudibranchia) with descriptions of 20 new species of Dermatobranchus. Zoological Journal of the Linnean Society, 161, pp. 245-356.

GOSLINER, T.M. and GHISELIN, M.T. (1984) Parallel evolution in opisthobranch gastropods and its implications for phylo- genetic methodology. Systematic Zoology, 33 , pp. 255-274.

GOSLINER, T.M. and JOHNSON, R.F. (1999) Phylogeny of Hypselodoris (Nudibranchia: Chromodorididae) with a review of the monophyletic clade of Indo-Pacific species, including descriptions of twelve new species. Zoological Journal of the Linnean Society, 125, pp. 1-113.

GOSLINER, T.M., ORTEA, J. and VALDÉS, A. (2004) New data on tropical eastern Pacific Chromodorididae (Nudibranchia: Doridina) with description of a new species of Mexichromis Bertsch, 1977. Proceedings of the California Academy of Sciences, 55, pp. 588-597.

GRAHAM, A. (1988) Molluscs: Prosobranch and pyramidellid gastropods. Synopsis of the British Fauna (New Series), No. 2 (second edition). Linnean Society of London and The Estuarine and Brackish Water Sciences Association. EJ Brill/ Dr W Backhuys.

GRANDE, C., TEMPLADO, J., CERVERA, J.L. and ZARDOYA, R. (2004) Molecular phylogeny of Euthyneura (Mollusca: Gastropoda). Molecular Biology and Evolution, 21, pp. 303-313.

HASSELT, J.C. Van (1824) Uittreksel uit eenen brief van Dr. J.C. van Hasselt, aan Prof. van Swinderen. Algemeene Konst- en Letterbode, 1824 (3), pp. 34-39.

HASZPRUNAR, G. (1988) On the origin and evolution of major gastropod groups, with special reference to the Streptoneura. Journal of Molluscan Studies, 54, pp. 367-441.

HUBER,G. (1993) On the cerebral nervous system of marine Heterobranchia (Gastropoda). Journal ofMolluscan Studies,59, pp. 381-420.

JENSEN, K.R. (1996) Phylogenetic systematics and classification of the Sacoglossa (Mollusca, Gastropoda, Opisthobranchia). Philosophical Transactions of the Royal Society, B 351: 91122.

JENSEN, K.R. (1999) Collection, preservation and identification of opisthobranch molluscs. Phuket Marine Biological Center Special Publication, 19, pp. 345-352.

JENSEN, K.R. (2000) Classification of the Superorder Heterobranchia: Overview and literature. Phuket Marine Biological Center Special Publication, 21, pp. 613-628.

JENSEN, K.R. (2007) Biogeography of the Sacoglossa (Mollusca, Opisthobranchia). Bonner Zoologische Beiträge, 55, pp. 255281. 
JENSEN, K.R. (2011) Comparative morphology of the mantle cavity organs of shelled Sacoglossa, with a discussion of relationships with other Heterobranchia. Thalassas, 27, pp. 169-192.

JOHNSON, R.F. (2010) Breaking family ties: taxon sampling and molecular phylogeny of chromodorid nudibranchs (Mollusca, Gastropoda). Zoologica Scripta, 40, pp. 137157.

JOHNSON, R.F. and GOSLINER, T.M. (1998) The genus Pectenodoris (Nudibranchia: Chromodorididae) from the Indo-Pacific, with the description of a new species. Proceedings of the California Academy of Sciences, 50, pp. 295-306.

JOHNSON, R.F. and GOSLINER, T.M. (2001) Two new species of Thorunna Bergh 1878 (Mollusca: Nudibranchia: Chromodorididae) from the Indo-Pacific. Bollettino Malacologico, 37, pp. 143-150.

JOHNSON, R.F. and GOSLINER, T.M. (2012) Traditional taxonomic groupings mask evolutionary history: A molecular phylogeny and new classification of the chromodorid nudibranchs. PLoS ONE, 7, pp. e33479 (doi: 10.1371/journal.pone.0033479).

JOHNSON, R.F. and VALDES, A. (2001) The Hypselodoris infucata, $H$. obscura and $H$. saintvincentius species complex (Mollusca, Nudibranchia, Chromodorididae), with remarks on the genus Brachychlanis Ehrenberg, 1831. Journal of Natural History, 35, pp. 1371-1398.

JÖRGER, K.M., STÖGER, I., KANO, Y., FUKUDA, H., KNEBELSBERGER, T. and SCHRÖDL, M. (2010) On the origin of Acochlidia and other enigmatic euthyneuran gastropods, with implications for the systematics of Heterobranchia. BMC Evolutionary Biology, 10, pp. 323 (doi: 10.1186/1471-2148-10-323).

KAWAGUTI, S. and BABA, K. (1959) A preliminary note on a two-valvedsacoglossan gastropod, Tamanovalva limax n.gen., n.sp., from Tamano, Japan. Biological Journal of Okayama University, 5, 177-184.

KHUROO, A.A., DAR, G.H., KHAN, Z.S. and MALIK, A.H. (2007) Exploring an inherent interface between taxonomy and biodiversity: Current problems and future challenges. Journal for Nature Conservation, 15, pp. 256-261.
KLUSSMANN-KOLB,A. (2004) Phylogeny of the Aplysiidae (Gastropoda, Opisthobranchia) with new aspects of the evolution of seahares. Zoologica Scripta, 33, pp. 439-462.

KLUSSMANN-KOLB, A. and DINAPOLI, A. (2006) Systematic position of the pelagic Thecosomata and Gymnosomata within Opisthobranchia (Mollusca, Gastropoda)revival of the Pteropoda. Journal of Zoological Systematics and Evolutionary Research, 44, pp. 118-129.

KLUSSMANN-KOLB， A., DINAPOLI, A., KUHN, K., STREIT, B. and ALBRECHT, C. (2008) From sea to land and beyond-New insights into the evolution of euthyneuran Gastropoda (Mollusca). BMC Evolutionary Biology, 8, pp. 57 (doi: 10.1186/1471-21488-57).

MACE, G.M. (2004) The role of taxonomy in species conservation. Philosophical Transactions of the Royal Society of London $B, 359$, pp. 711-719.

MALAQUIAS, M.A.E., MACKENZIE-DODDS, J., BOUCHET, P., GOSLINER, T. and REID, D.G. (2009). A molecular phylogeny of the Cephalaspidea sensulato (Gastropoda: Euthyneura): Architectibranchia redefined and Runcinacea reinstated. Zoologica Scripta, 38: 23-41.

MIKKELSEN, P.M. (1996) The evolutionary relationships of Cephalaspidea s.l. (Gastropoda: Opisthobranchia): A phylogenetic analysis. Malacologia, 37, pp. 375-442.

MIKKELSEN, P.M. (1998) Review of shell reduction and loss in traditional and phylogenetic systematics, with experimental manipulation of a negative gain character. American Malacological Bulletin, 14, pp. 201-218.

MIKKELSEN, P.M. and CRACRAFT, J. (2001) Marine biodiversity and the need for systematic inventories. Bulletin of Marine Science, 69, pp. 525-534.

MORRISON, W.R. III, LOHR, J.L., DUCHEN, P., WILCHES, R., TRUJILLO, D., MAIR, M. and RENNER, S.S. (2009) The impact of taxonomic change on conservation: Does it kill, can it save, or is it just irrelevant? Biological Conservation, 142, pp. 3201-3206.

MORTON, B. (2003) Hong Kong's international malacological, wetland and marine biological workshops (1977-1998): changing local attitudes towards marine conservation. In: MORTON, B. (ed.) Perspectives on Marine Environment Change in Hong Kong and 
Southern China, 1977-2001. Hong Kong: Hong Kong University Press, pp. 31-71.

NEUSSER, T.P., FUKUDA, H., JÖRGER, K.M., KANO, Y. and SCHRÖDL, M. (2011) Sacoglossa or Acochlidia? 3D reconstruction, molecular phylogeny and evolution of Aitengidae (Gastropoda: Heterobranchia). Journal of Molluscan Studies, 77, pp. 332350.

ONO, A. (1999) Opisthobranchs of Kerama Islands. Tokyo: TBS-Britannica \& Co., Ltd.

PEARSON, D.L., HAMILTON, A.L. and ERWIN, T.L. (2011) Recovery plan for the endangered taxonomy profession. BioScience, 61, pp. 58-63.

PLEIJEL, F., JONDELIUS, U., NorLinder, E., NYGREN, A., OXELMAN, B., SCHANDER, C., SUNDBERG, P. and THOLLESSON, M. (2008) Phylogenies without roots? A plea for the use of vouchers in molecular phylogenetic studies. Molecular Phylogenetics and Evolution, 48, pp. 369371.

RENNER, S.C., NEUMANN, D., BURKART, M., FEIT, U., GIERE, P., GRÖGER, A., PAULSCH, A., PAULSCH, C., STERZ, M. and VOHLAND, K. (2012) Import and export of biological samples from tropical countries-considerations and guidelines for research teams. Organisms Diversity \& Evolution, 12, pp. 81-98.

RUDMAN, W.B. (1982) The Chromodorididae (Opisthobranchia: Mollusca) of the IndoWest Pacific: Chromodoris quadricolor, $C$. lineolata and Hypselodoris nigrolineata colour groups. Zoological Journal of the Linnean Society, 76, pp. 183-241.

RUDMAN, W.B. (1983) The Chromodorididae (Opisthobranchia: Mollusca) of the IndoWest Pacific: Chromodoris splendida, $C$. aspersa and Hypselodoris placidacolour groups. Zoological Journal of the Linnean Society, 78, pp. 105-173.

RUDMAN, W.B. (1984) The Chromodorididae (Opisthobranchia: Mollusca) of the IndoWest Pacific: a review of the genera. Zoological Journal of the Linnean Society, 81, pp. 115-273.

RUDMAN, W.B. (1985) The Chromodorididae (Opisthobranchia: Mollusca) of the IndoWest Pacific: Chromodoris aureomarginata, $C$. verrieri and $C$. fidelis colour groups. Zoological Journal of the Linnean Society, 83, pp. 241-299.
RUDMAN, W.B. (1986a) The Chromodorididae (Opisthobranchia: Mollusca) of the IndoWest Pacific: the genus Glossodoris Ehrenbergh (=Casella H. \& A. Adams). Zoological Journal of the Linnean Society, 86, pp. 101-184.

RUDMAN, W.B. (1986b) The Chromodorididae (Opisthobranchia: Mollusca) of the IndoWest Pacific: Noumea purpurea and Chromodoris decora colour groups. Zoological Journal of the Linnean Society, 86, pp. 309-353.

RUDMAN, W.B. (1986c). The Chromodorididae (Opisthobranchia: Mollusca) of the IndoWest Pacific: Noumea flava colour group. Zoological Journal of the Linnean Society, 88, pp. 377-404.

RUDMAN, W.B. (1987) The Chromodorididae (Opisthobranchia: Mollusca) of the IndoWest Pacific: Chromodoris epicuria, $C$. aureopurpurea, C. annulata, C. coi and Risbecia tryoni colour groups. Zoological Journal of the Linnean Society, 90, pp. 305407.

RUDMAN, W.B. (1988) The Chromodorididae (Opisthobranchia: Mollusca) of the IndoWest Pacific: The genus Ceratosoma J.E. Gray. Zoological Journal of the Linnean Society, 93, pp. 133-185.

RUDMAN, W.B. (1990) The Chromodorididae (Opisthobranchia: Mollusca) of the IndoWest Pacific: further species of Glossodoris, Thorunna and the Chromodoris aureomarginata colour group. Zoological Journal of the Linnean Society, 100, pp. 263326.

RUDMAN, W.B. (1995) The Chromodorididae (Opisthobranchia: Mollusca) of the IndoWest Pacific: further species from New Caledonia and the Noumea romeri colour group. Molluscan Research, 16, pp. 1-43.

SCHANDER, C. and WILLASSEN, E. (2005) What can biological barcoding do for marine biology? Marine Biology Research, 1, pp. 7983.

SCHMEKEL, L. (1985) Aspects of evolution within the opisthobranchs. In: TRUEMAN, E.R. and CLARKE, M.R. (eds.) The Mollusca. Vol 10: Evolution. New York: Academic Press, pp. 221-267.

SCHRÖDL, M. (2003) Sea Slugs of Southern South America. Systematics, biogeography and biology of Chilean and Magellanic Nudipleura (Mollusca: Opisthobranchia). Hackenheim: ConchBooks. 
SCHRÖDL, M., JÖRGER, K.M., KLUSSMANNKOLB, A. and WILSON, N.G. (2011) Bye bye "Opisthobranchia"! A review on the contribution of mesopsammic sea slugs to euthyneuran systematics. Thalassas, 27, pp. 101-112.

SWENNEN, C. (2001) Two new sacoglossans (Gastropoda: Opisthobranchia) from Thailand. Beaufortia Bulletin Zoologisch Museum Universiteit van Amsterdam, 51, pp. 75-81.

SWENNEN, C. (2007) Costasiella coronata, new species, and a revised diagnosis for the family Costasiellidae (Mollusca: Opisthobranchia: Sacoglossa). Raffles Bulletin of Zoology, 55, pp. 355-362.

SWENNEN, C. (2011) Large mangrove-dwelling Elysia species in Asia, with descriptions of two new species (Gastropoda: Opisthobranchia: Sacoglossa). Raffles Bulletin of Zoology, 59, pp. 29-37.

SWENNEN, C. and BUATIP, S. (2009) Aitengater, new genus, new species, an amphibious and insectivorous sea slug that is difficult to classify [Mollusca: Gastropoda: Opisthobranchia: Sacoglossa(?): Aitengidae, new family]. Raffles Bulletin of Zoology, 57, pp. 495-500.

THOLLESSON, M. (1999) Phylogenetic analysis of Euthyneura (Gastropoda) by means of the 16S rRNA gene: the use of a 'fast' gene for 'higher-level' phylogenies. Proceedings of Royal Society of London B, 266, pp. 75-83.

TURNER, L.M. and WILSON, N.G. (2008) Polyphyly across oceans: a molecular phylogeny of the Chromodorididae (Mollusca, Nudibranchia). Zoologica Scripta, 37, pp. 23-42.

VALDÉS, A. and ADAMS, M.J. (2005) A new species of Glossodoris (Mollusca: Nudibranchia), of the Glossodoris atromarginata color group, from Indonesia. Pacific Science, 59 , pp. 603-608.

VALDÉS, A. and GOSLINER, T.M. (1999) Reassessment of the systematic status of Miamara Bergh, 1875 and Orodoris Bergh, 1875 (Nudibranchia: Chromodorididae) in light of phylogenetic analysis. Journal of Molluscan Studies, 65, pp. 33-45.

VALDÉS, A., et al. (2006) Caribbean Sea Slugs. A field guide to the opisthobranch mollusks from the tropical northwestern Atlantic. Washington: Sea Challengers Natural History Books, Etc., Gig Harbor.
VALDÉS, A., MOLLO, E. and ORTEA, J. (1999) Two new species of Chromodoris (Mollusca, Nudibranchia, Chromodorididae) from Southern India, with a redescription of Chromodoris trimarginata (Winckworth, 1946). Proceedings of the California Academy of Sciences, 51, pp. 461-472.

WÄGELE, H. and KLUSSMANN-KOLB, A. (2005) Opisthobranchia (Mollusca, Gastropoda)-more than just slimy slugs. Shell reduction and its implications on defence and foraging. Frontiers in Zoology, 2, 3 (doi: 10.1186/1742-9994-2-3).

WÄGELE, H., et al. (2011) The taxonomist - an endangered race. A practical proposal for its survival. Frontiers in Zoology, 8, pp. 25 (doi: 10.1186/1742-9994-8-25).

WÄGELE, H., et al. (2008) Heterobranchia I: the Opisthobranchia. In: PONDER, W.F. and LINDBERG, D.(eds.) Phylogeny and Evolution of the Mollusca. Berkeley: University of California Press, pp. 385-408.

WÄGELE, H. and WILLAN, R.C. (2000) Phylogeny of Nudibranchia. Zoological Journal of the Linnean Society, 130, pp. 83181.

WELLS, F.E. and BRYCE, C.W. (1993) Sea Slugs and their Relatives of Western Australia. Perth: Western Australian Museum.

WHEELER, Q.D., RAVEN, P.H. and WILSON, E.O. (2004) Taxonomy: Impediment or expedient. Science, 303, pp. 285.

WILLAN, R.C. (1987) Phylogenetic systematics of the Notaspidea (Opisthobranchia) with reappraisal of families and genera. American Malacological Bulletin, 5, pp. 215-241.

WOLLSCHEID-LENGELING, E., BOORE, J.L., BROWN, W.M. and WÄGELE, H. (2001) The phylogeny of Nudibranchia (Opisthobranchia, Gastropoda, Mollusca) reconstructed by three molecular markers. Organisms Diversity \& Evolution, 1, 241256.

YONOW, N. (2001) Results of the Rumphius Biohistorical Expedition to Ambon (1990). Part 11. Doridacea of the families Chromodorididae and Hexabranchidae (Mollusca, Gastropoda, Opisthobranchia, Nudibranchia), including additional Moluccan material. Zoologische Mededelingen, Leiden, 75, pp. 1-50.

YONOW, N. (2008) Sea Slugs of the Red Sea. Moscow: Pensoft Publishers, Sofia. 
YONOW, N. (2011) Results of the Rumphius Biohistorical Expedition to Ambon (1990).

Diterima: 27 September 2013 Part 15. The suborder Doridina (Mollusca, Disetujui: 10 Oktober 2013 Gastropoda, Opisthobranchia, Nudibranchia). Zoologische Mededelingen, Leiden, 85, pp. 905-956. 